\title{
Feeding ecology and trophic position of three sympatric demersal chondrichthyans in the northwestern Mediterranean
}

\author{
Marta Albo-Puigserver ${ }^{1, *}$, Joan Navarro ${ }^{1,2}$, Marta Coll $^{1,3}$, Jacopo Aguzzi $^{1}$, \\ Luis Cardona ${ }^{4}$, Raquel Sáez-Liante ${ }^{1}$
}

\author{
${ }^{1}$ Institut de Ciències del Mar (ICM-CSIC), Passeig Marítim de la Barceloneta, 37-49, 08003 Barcelona, Spain \\ ${ }^{2}$ Department of Conservation Biology, Estación Biológica de Doñana (EBD-CSIC), Avda. Américo Vespucio s/n, \\ Sevilla 41092, Spain
}

${ }^{3}$ Laboratoire Écosystèmes Marins Exploités UMR 212, IRD-IFREMER-UM2, Avenue Jean Monnet BP171, 34203 Sète Cedex, France

${ }^{4}$ Departament de Biologia Animal and Institut de Recerca de la Biodiversitat (IRBio), Facultat de Biologia Universitat de Barcelona, Avinguda Diagonal 645, 08028 Barcelona, Spain

\begin{abstract}
Understanding how marine predators interact is a scientific challenge. In marine ecosystems, segregation in feeding habits has been largely described as a common mechanism to allow the coexistence of several competing marine predators. However, little is known about the feeding ecology of most species of chondrichthyans, which play a pivotal role in the structure of marine food webs worldwide. In this study, we examined the trophic ecology of 3 relatively abundant chondrichthyans coexisting in the Mediterranean Sea: the blackmouth catshark Galeus melastomus, the velvet belly lanternshark Etmopterus spinax and the rabbit fish Chimaera monstrosa. To examine their trophic ecology and interspecific differences in food habits, we combined the analysis of stomach content and stable isotopes. Our results highlighted a trophic segregation between C. monstrosa and the other 2 species. G. melastomus showed a diet composed mainly of cephalopods, while E. spinax preyed mainly on shrimps and C. monstrosa on crabs. Interspecific differences in the trophic niche were likely due to different feeding capabilities and body size. Each species showed different isotopic niche space and trophic level. Specifically, $C$. monstrosa showed a higher trophic level than E. spinax and G. melastomus. The high trophic levels of the 3 species highlighted their important role as predators in the marine food web. Our results illustrate the utility of using complementary approaches that provide information about the feeding behaviour at short (stomach content) and long-term scales (stable isotopes), which could allow more efficient monitoring of marine food-web changes in the study area.
\end{abstract}

KEY WORDS: Feeding niche $\cdot$ Isotope analysis $\cdot$ Mediterranean Sea $\cdot$ Galeus melastomus Etmopterus spinax $\cdot$ Chimaera monstrosa

Resale or republication not permitted without written consent of the publisher

\section{INTRODUCTION}

Based on the principle of competitive exclusion, species exploiting similar niches are expected to result in ecological divergence or exclusion (Gause 1934, Pianka 2000). However, in some cases, closely related species can coexist (Grant 1972). Partitioning of food resources has been proposed as one of the main mechanisms explaining the coexistence of competing marine predators such as marine mammals, seabirds, sharks and other predatory fishes (Platell \& Potter 2001, Papastamatiou et al. 2006, Cherel et al. 2008, Kiszka et al. 2011, Mèndez-Fernandez et al. 2012). 
The Mediterranean Sea is oligotrophic, and food resources in deep waters are considered scarce (Estrada 1996, Turley et al. 2000), a situation that could lead to a high level of competition between species. Consequently, an increase in niche segregation among closely related sympatric species would be expected. This interspecific pressure would ultimately lead to food partitioning, a hypothesis that is tested here in Mediterranean deep-water areas using 3 abundant demersal chondrichthyans that exploit similar resources: the blackmouth catshark Galeus melastomus, the velvet belly lanternshark Etmopterus spinax and the rabbit fish Chimaera monstrosa.

Previous diet studies conducted on G. melastomus and E. spinax in the Mediterranean Sea indicated contrasting patterns: while some studies indicated that the 2 species segregate their trophic habits (Carrassón et al. 1992, Cortés 1999, Stergiou \& Karpouzi 2002, Fanelli et al. 2009), others suggested a clear overlap in their diets (Valls et al. 2011). For the Mediterranean populations of C. monstrosa, there is a lack of knowledge about feeding ecology (MacPherson 1980, Abdul Malak et al. 2011), and this species has been classified as Data Deficient in the Mediterranean Sea and as Near Threatened globally by the International Union for Conservation of Nature (Abdul Malak et al. 2011). Moreover, there are no studies that simultaneously examine the trophic ecology of these 3 relatively abundant species from the same area, information that can provide, in addition to their feeding habits, insights into their level of potential trophic overlap or segregation.

The study of feeding ecology of marine predators has traditionally relied on stomach content sampling (Cortés 1999, Stergiou \& Karpouzi 2002). Although such data permits high levels of taxonomic resolution, sharks often have empty stomachs, and the prey that are recovered are often skewed toward those that are difficult to digest (Hyslop 1980). Moreover, stomach content analyses generally require large sample sizes to accurately quantify long-term feeding patterns (Hyslop 1980, Cortés 1999), which are difficult to obtain for most species of sharks (Stergiou $\&$ Karpouzi 2002, MacNeil et al. 2005). The use of stable isotopes of nitrogen $\left(\delta^{15} \mathrm{~N}\right)$ and carbon $\left(\delta^{13} \mathrm{C}\right)$ has been used as an alternative and complementary tool to study the feeding ecology, trophic position and niche width of predators including chondrichthyans (Hussey et al. 2012, Layman et al. 2012, Shiffman et al. 2012). This approach is based on the fact that $\delta^{15} \mathrm{~N}$ and $\delta^{13} \mathrm{C}$ values are transformed from dietary sources to consumers in a predictable manner (Kelly 2000) and integrates the diet of the consumer over a longer time period (i.e. close to $1 \mathrm{yr}$ for the elasmobranch muscle; Caut et al. 2013). $\delta^{15} \mathrm{~N}$ values show a stepwise enrichment between 2 and $5 \%$ with each trophic level and are reliable indicators of the consumer's trophic positions (Layman et al. 2012). $\delta^{13} \mathrm{C}$ values show little change due to trophic transfer but are useful indicators of dietary sources of carbon (Layman et al. 2012). Moreover, by analysing both $\delta^{15} \mathrm{~N}$ and $\delta^{13} \mathrm{C}$ data together, it is possible to estimate trophic width of species by calculating the isotopic area (Layman et al. 2012). Similarly, by combining stable isotope values for consumers with those of their potential prey, isotopic mixing models can be applied to interpret the isotopic values by estimating the relative contribution of each prey item to the diet of the consumer (e.g. Stable Isotope Analysis in R [SIAR] isotopic mixing model; Parnell et al. 2010). Although outcomes of stomach content and isotopic analysis need to be interpreted with caution and may not be directly comparable, their combination is highly useful to better understand the trophic ecology of organisms at different time-scales and resolution (Shiffman et al. 2012, Caut et al. 2013, Navarro et al. 2014, Phillips et al. 2014).

In the present study, we examined the feeding ecology (diet habits, trophic width and trophic position) of 3 chondrichthyans-G. melastomus, E. spinax and C. monstrosa - coexisting in sympatry in the Gulf of Lions (NW Mediterranean) with the use of stable isotopic and stomach content approximations. Based on previous knowledge of the dietary habits of these species and taking in account that they coexist, we expected some degree of trophic partitioning between the species. Our study provides new insights into the ecological role of these 3 species within the demersal community, obtaining new data on how these 3 relatively abundant demersal chondrichthyans exploit available resources.

\section{MATERIALS AND METHODS}

\section{Study species and area}

Galeus melastomus is a small shark with a wide bathymetric range of distribution in the Mediterranean Sea and Eastern and Central Atlantic Ocean (distributed from 200 to $1400 \mathrm{~m}$ depth; Carrassón et al. 1992). This species is considered a trophic generalist, preying on shrimps, cephalopods, fishes and euphausiids (Carrassón et al. 1992, Olaso et al. 2005, Fanelli et al. 2009, Valls et al. 2011). In the SW Mediterran- 
ean, the size at first maturity was determined at 44.3 and 48.8 (cm, total length) for males and females, respectively (Rey et al. 2004). Etmopterus spinax has a similar geographical distribution to G. melastomus, occupying a wider depth range (from 70 to $2000 \mathrm{~m}$ depth; Sion et al. 2004). Mature individuals are distributed in deeper waters than immature ones, and they mainly prey upon shrimps, fish and cephalopods (Sion et al. 2004, Neiva et al. 2006, Fanelli et al. 2009, Valls et al. 2011). The total length at first maturity for males and females in the Southern Mediterranean Sea was reported at 35 and $38 \mathrm{~cm}$, respectively (Capape et al. 2001). The holocephalan Chimaera monstrosa is distributed between 300 and $1250 \mathrm{~m}$ depths throughout the Mediterranean and in the North and Central Eastern Atlantic Ocean (Calis et al. 2005). Its narrower diet spectrum mainly consists of benthic organisms (e.g. crabs and ophiurans; MacPherson 1980, Moura et al. 2005). Size at first maturity for males and females was reported in the southern continental slope of Portugal at 40.7 and $45.9 \mathrm{~cm}$, respectively (Moura et al. 2004).

The present study was conducted in the Gulf of Lions, in the NW Mediterranean (Fig. 1). This area is located at depths of 400 to $700 \mathrm{~m}$ depth. Although not evaluated in the present study, we expected that the resource availability in the demersal compartment was scarce due to the general oligotrophy and depth of the area (Estrada 1996, Turley et al. 2000), a situation that could lead to a high level of competition for trophic resources between species. This area has been proposed as a Fisheries Restricted Area (FRA)

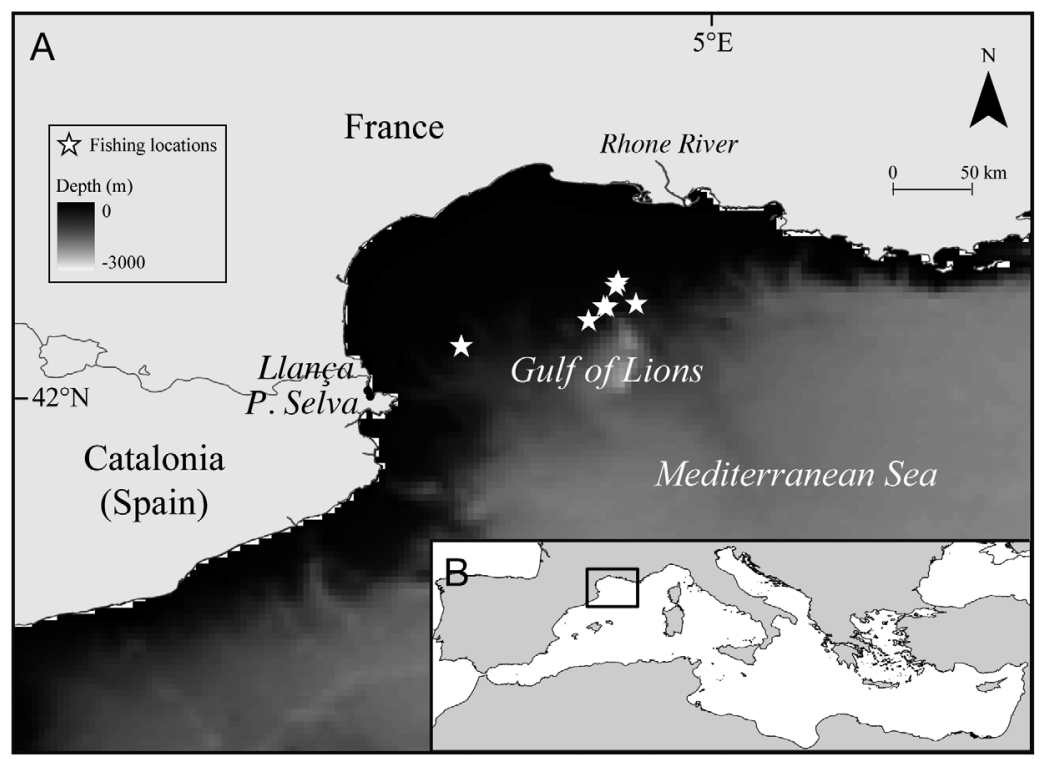

Fig. 1. Study area (Gulf of Lions, NW Mediterranean), indicating the sampling locations (white stars) due to its importance as a refuge for large spawning aggregations of commercially fished species. Since the area is far from the coast, it has been less exploited than other Mediterranean continental shelves and slopes (Coll et al. 2012, Massutí et al. 2012).

\section{Sampling procedure}

Stomach content and stable isotope analyses were carried out on specimens of $G$. melastomus ( $\mathrm{n}=34$ ), E. spinax $(\mathrm{n}=36)$ and C. monstrosa $(\mathrm{n}=24)$ collected from June to August of 2011 at similar depths, with a mean (and standard deviation) depth of 489 ( \pm 74$) \mathrm{m}$. All specimens were captured in the Gulf of Lions by trawlers based at Port de la Selva and Llançà ports in Catalonia (Fig. 1). They were captured accidentally and were part of the by-catch species of the fishing fleet. Each specimen was immediately frozen on board after capture and stored at $-20^{\circ} \mathrm{C}$ until their morphological, stomach content and tissue-isotopic analyses were conducted.

The sex, preanal body length (i.e. from the anus to the head, in $\mathrm{cm}$ ), total body length (in $\mathrm{cm}$ ) and body mass (in g) of each specimen were recorded. We used the preanal body length to compare between species because this measure is more accurate than total body length for $C$. monstrosa since this species frequently presents broken tails when captured. We also recorded the maturity state as immature or mature of each individual, following the protocol by Stehmann (2002). In the case of males, the maturity state was determined according to the degree of calcification of the clasper and the degree of development of the testes and reproductive ducts. In the case of females, the maturity state was determined by the condition of uteri, oviducal glands and ovarian follicles (Stehmann 2002). Furthermore, possible maternal effects in the isotopic signal of immature E. spinax were discarded. According to their total length, all individuals of $E$. spinax analysed had more than 1 estimatedyear (Gennari \& Scacco 2007, Olin et al. 2011).

\section{Stomach content}

The stomach of all specimens was extracted after dissection in the labo- 
ratory. Each stomach was weighed in a digital balance, and its contents were extracted. All prey items found in the stomach were carefully separated, dried on paper towels, counted, weighed to the nearest $0.001 \mathrm{~g}$ and classified into 4 groups: cephalopods, crabs, shrimps and fish. We did not classify the prey items at species level to be consistent with the dietary estimations obtained with the stable isotopic values (see following 'Stable isotope analyses' and 'Isotopic mixing models' sections). Whenever fragments of prey were found, the number of counted individuals was the lowest possible that these fragments could have originated from to avoid overestimation of the occurrence of a particular prey.

To assess the importance of different prey groups in the diet, and to compare between the 3 species, the combined Index of Relative Importance (Pinkas et al. 1971) was used:

$$
\operatorname{IRI}_{i}=\left(\mathrm{N}_{i}+\mathrm{W}_{i}\right) \cdot \mathrm{FO}_{i}
$$

where $\mathrm{FO}_{i}$ is the frequency of occurrence of a type of prey group (i) in relation to the total number of stomachs, $\mathrm{N}_{i}$ is the contribution by number of a type of prey group (i) in relation to the whole content of the stomach, and $\mathrm{W}_{i}$ is the wet weight of a type of prey group (i) in relation to the whole content of the stomach. All calculations were based on the number of non-empty stomachs. To allow comparisons between prey groups and species, the IRI was expressed as a percentage (Cortés 1997):

$$
\% \mathrm{IRI}_{i}=100 \cdot \mathrm{IRI}_{i} / \Sigma_{\mathrm{i}=1}^{\mathrm{n}} \mathrm{IRI}_{i}
$$

The vacuity index $(\% \mathrm{~V})$ was also calculated as the percentage of empty stomachs.

\section{Stable isotope analyses}

A small portion of dorsal muscle (without skin and cartilage) was extracted from each specimen. Muscle from different prey belonging to the identified groups (crabs, shrimps, cephalopods and fish) was also collected. The use of prey from the stomach content for the isotope analysis is a methodology used in different studies with sharks and other marine predators (e.g. Ramos et al. 2009, Moreno et al. 2010, Chiaradia et al. 2012, Caut et al. 2013, Navarro et al. 2014). This is an alternative when potential prey from the field cannot be obtained. The main limitation is to use only fresh items to reduce the potential biases due to digestion. For this reason, we only selected prey items that were entire or those hard structures of prey (such beaks of cephalopods) that were not affected and degraded by the digestion process. Moreover, the advantage of using prey from the stomach content is that we have the certainty that it is a real prey eaten by the predator. Since cephalopod beaks are depleted in $\delta^{15} \mathrm{~N}$ compared to muscle tissues, the $\delta^{15} \mathrm{~N}$ values of beaks were adjusted by adding $3.5 \%$ to their $\delta^{15} \mathrm{~N}$ values (Cherel et al. 2009). All samples were freeze-dried and powdered, and 0.9 to $1.0 \mathrm{mg}$ of each sample was packed into tin capsules. Isotopic analyses were performed at the Laboratory of Stable Isotopes of the Estación Biológica de Doñana (www.ebd.csic.es/lie/index.html). Samples were combusted at $1020^{\circ} \mathrm{C}$ using a continuous flow isotope-ratio mass spectrometry system (Thermo Electron) by means of a Flash HT Plus elemental analyser interfaced with a Delta V Advantage mass spectrometer. Stable isotope ratios were expressed in the standard $\delta$-notation (\%) relative to Vienna Pee Dee Belemnite $\left(\delta^{13} \mathrm{C}\right)$ and atmospheric $\mathrm{N}_{2}\left(\delta^{15} \mathrm{~N}\right)$. Based on laboratory standards, the measurement error was \pm 0.1 and \pm 0.2 for $\delta^{13} \mathrm{C}$ and $\delta^{15} \mathrm{~N}$, respectively. The C:N ratio of all tissues was always $<3.5 \%$, and hence, no correction of the $\delta^{13} \mathrm{C}$ values was required to account for the presence of lipids (Logan et al. 2008).

\section{Isotopic niche and isotopic mixing models}

As a measure of trophic width, we calculated the Bayesian isotopic ellipse area $\left(\mathrm{SEA}_{B}\right)$ for each species and standard ellipses corrected for small sample sizes $\left(\mathrm{SEA}_{\mathrm{C}}\right)$ to compare the degree of isotopic niche overlap between species (Jackson et al. 2011). This metric represents a measure of the total amount of isotopic niche exploited by a particular predator and is thus a proxy for the extent of trophic diversity (or trophic width) exploited by the species considered (high values of isotopic standard ellipse areas indicate high trophic width). This metric uses multivariate ellipse-based Bayesian metrics. Bayesian inference techniques allow for robust statistical comparisons between data sets with different sample sizes (Jackson et al. 2011, Syväranta et al. 2013). Isotopic standard ellipse areas and their overlap were calculated using the routine Stable Isotope Bayesian Ellipses (SIBER; Jackson et al. 2011) also incorporated in the SIAR library.

To estimate the potential contribution of the different potential prey to the diet of each species (in proportional terms), we adopted a Bayesian multi-source isotopic mixing model (SIAR 4.1.3). The SIAR model estimates the potential contribution of each prey in 
the diet based on their muscle isotopic values and those of their potential prey. This model runs under the free software R (R Development Core Team 2009) and allows the inclusion of sources of uncertainty in the data, in particular the variability in the stable isotope ratios of the predator and the potential prey (Parnell et al. 2010). The accurate use of isotopic mixing models is always limited by the correct knowledge and application of the diet tissue discrimination factor (DTDF) of $\delta^{13} \mathrm{C}\left(\Delta^{13} \mathrm{C}\right)$ and $\delta^{15} \mathrm{~N}\left(\Delta^{15} \mathrm{~N}\right)$ (Phillips et al. 2014). Recent studies highlighted that $\Delta^{15} \mathrm{~N}$ can vary greatly among consumers, tissues and diet composition (Martínez del Rio et al. 2009, Olin et al. 2013, Hussey et al. 2014), whereas the $\Delta^{13} \mathrm{C}$ vary little with trophic transfer (Layman et al. 2012). Different DTDF have been previously used in other studies dealing with chondrichthyan muscle (Hussey et al. 2010a, Kim et al. 2012, Caut et al. 2013, Olin et al. 2013). In our case, because no specific discrimination factor for our species is available, we used an incremental DTDF of $\delta^{15} \mathrm{~N}$ (from $1.5 \Delta^{15} \mathrm{~N}$ to $3.5 \Delta^{15} \mathrm{~N}$; following the approach of Hussey et al. 2010a) and different DTDF of $\Delta^{13} \mathrm{C}$ (Hussey et al. 2010b, Kim et al. 2012) to evaluate and obtain an overall picture of the possible prey contributions as a result of varying DTDF. Cephalopods, crabs, shrimps and fish were the prey groups included in the SIAR model in accordance with the classification of prey explained in the stomach content analysis (see 'Results'). Brittle stars (Ophiura) were included in the mixing model for $C$. monstrosa because this echinoderm has been described in the literature as an important prey for $C$. monstrosa (MacPherson 1980), although it did not occur in the samples analysed here. Therefore, stable isotope values of brittle stars were obtained from published values of the same area of study (Darnaude et al. 2004). Similarly, because the number of crabs analysed were very low, we also include isotopic values from crabs collected in the NW Mediterranean Sea (Carlier et al. 2007, Bautista-Vega et al. 2008, Papiol et al. 2013).

\section{Trophic level}

The trophic level (TL) indicates the trophic position of a species in the food web with regard to the TL of consumed prey. Here, we estimated the TL of each species by using stomach content $\left(\mathrm{TL}_{\text {stomach }}\right)$ and stable isotopic analysis ( $\mathrm{TL}_{\text {sia }}$ ).

The TL estimated with the stomach content was historically defined as an integer identifying the position of a particular organism within food webs, and it was later modified to be fractional. Following an established convention, we calculated the TL estimated with stomach content $\left(\mathrm{TL}_{\text {stomach }}\right)$ as the average value for each predator based on the importance of each prey in the diet using the following equation:

$$
\mathrm{TL}_{j}=1+\sum_{j-1}^{\mathrm{n}} \mathrm{DC}_{j i} \cdot \mathrm{TL}_{i}
$$

where $j$ is the predator of prey $i, \mathrm{DC}_{j i}$ is the fraction of prey $i$ in the diet of predator $j$ (\% IRI), and $\mathrm{TL}_{i}$ is the trophic level of prey $i$. The $\mathrm{TL}_{i}$ used were obtained from previous studies conducted in the NW Mediterranean Sea $\left(\mathrm{TL}_{\text {fish }}=3.05, \mathrm{TL}_{\text {shrimps }}=2.57 ; \mathrm{TL}_{\text {crabs }}=\right.$ 2.53; $\mathrm{TL}_{\text {cephalopods }}=3.63$; Coll et al. 2006, Bănaru et al. 2013).

We estimated the $\mathrm{TL}_{\text {sia }}$ of chondrichthyans based on isotopic values for each species according to the algorithm proposed by Vander Zanden \& Rasmussen (2001):

$\mathrm{TL}_{\text {consumers }}=\mathrm{TL}_{\text {basal }}+\left(\delta^{15} \mathrm{~N}_{\text {consumer }}-\delta^{15} \mathrm{~N}_{\text {basal }}\right) \Delta \delta^{15} \mathrm{~N}$

where $\delta^{15} \mathrm{~N}_{\text {consumer }}$ and $\delta^{15} \mathrm{~N}_{\text {basal }}$ were, respectively, the $\delta^{15} \mathrm{~N}$ values of each studied chondrichthyan and the annual average $\delta^{15} \mathrm{~N}$ values of microplankton, which were obtained from a study conducted in the Gulf of Lions by Costalago et al. (2012) $\left(\delta^{15} \mathrm{~N}_{\text {basal }}=\right.$ 3.93). $\Delta \delta^{15} \mathrm{~N}$ is the isotopic discrimination factor; in this case, we used the value published by Hussey et al. (2010b) for elasmobranch muscle tissue $(2.29 \%)$.

\section{Statistical analysis}

Interspecific differences in body length, body mass, $\%$ IRI, $\delta^{15} \mathrm{~N}$ and $\delta^{13} \mathrm{C}$ were tested by using 2 -way semi-parametric permutation multivariate analyses of variance tests (PERMANOVA test) on the Euclidean distance matrix (Anderson et al. 2008). In the case of a significant result, pairwise tests were performed. PERMANOVA allows for the analysis of complex designs (multiple factors and their interaction) without the constraints of multivariate normality, homoscedasticity and having a greater number of variables than sampling units of traditional ANOVA tests. The method calculates a pseudo- $F$ statistic directly analogous to the traditional F-statistic for multifactorial univariate ANOVA models, using permutation procedures to obtain $\mathrm{p}$-values for each term in the model (Anderson et al. 2008). PERMANOVA tests were carried out with PRIMER-E 6 software. The relationship between isotopic values and body size (using the anal length as standard measure) was explored using linear regression. Significance level for all tests was adopted at $\mathrm{p}<0.05$. 


\section{RESULTS}

\section{Body mass and body length}

The body mass and body length differed significantly between species and sexes (Tables 1 \& 2). In particular, Chimaera monstrosa showed the highest values of body mass and body length, followed by Galeus melastomus and Etmopterus spinax (Table 1). Between sexes, females showed the highest values of body mass and body length in the 3 species (Table 1). Since all the individuals analysed of G. melastomus and C. monstrosa were mature and all the individuals of E. spinax were immature, we did not consider the effect of the maturity state in our statistical analyses.

\section{Stomach content analysis}

The vacuity index differed among species: $47.22 \%(\mathrm{n}=17)$ of $E$. spinax, $8.82 \%(\mathrm{n}=3)$ of $G$. melastomus, and $0 \%(\mathrm{n}=0)$ of C. monstrosa were empty. Based on the \%IRI, the diet composition of these 3 species did not differ between sexes ( $p>$ 0.05 for the 3 species) but was clearly different among the species (Table 3). In particular, the stomach content of G. melastomus was composed mainly of cephalopods (\%IRI $=47.26)$, that of E. spinax of shrimps $(\% \operatorname{IRI}=45.60)$, and that of C. monstrosa was largely dominated by crabs (\%IRI $=96.98)$. However, it should be noted that in E. spinax, the percentage of unidentified prey was very high $(\% \mathrm{IRI}=36.13)$. The cumulative prey group curve for the overall diet of the 3 species
Table 1. Sample size (n) and mean $( \pm \mathrm{SD})$ body mass $(\mathrm{g})$ and anal body length $(\mathrm{cm})$ of males and females Galeus melastomus, Etmopterus spinax and Chimaera monstrosa from the Gulf of Lions (NW Mediterranean)

\begin{tabular}{|lcccc|}
\hline & $\mathrm{n}$ & Body mass & $\begin{array}{c}\text { Anal body } \\
\text { length }\end{array}$ & $\begin{array}{c}\text { Total body } \\
\text { length }\end{array}$ \\
\hline $\begin{array}{l}\text { G. melastomus } \\
\text { Males }\end{array}$ & 17 & $321.88 \pm 42.05$ & $21.48 \pm 0.82$ & $50.38 \pm 1.87$ \\
Females & 17 & $457.86 \pm 110.28$ & $23.98 \pm 1.83$ & $55.49 \pm 3.46$ \\
E. spinax & & & & \\
Males & 15 & $37.98 \pm 11.21$ & $12.28 \pm 2.45$ & $21.84 \pm 1.65$ \\
Females & 21 & $49.69 \pm 26.03$ & $13.67 \pm 2.85$ & $23.84 \pm 4.60$ \\
$\begin{array}{l}\text { C. monstrosa } \\
\text { Males }\end{array}$ & 12 & $658.67 \pm 100.35$ & $21.24 \pm 1.71$ & $72.34 \pm 7.08$ \\
Females & 12 & $1098.17 \pm 127.54$ & $24.98 \pm 1.39$ & $79.73 \pm 12.65$ \\
\hline
\end{tabular}

Table 2. PERMANOVA test results on the presence of significant differences of anal body length, body mass, $\delta^{15} \mathrm{~N}$ and $\delta^{13} \mathrm{C}$ values between Galeus melastomus (GM), Chimaera monstrosa (CM) and Etmopterus spinax (ES) from the Gulf of Lions (NW Mediterranean). Symbols designating species combinations are indicated in pairwise test summaries. Pairs of means differing significantly $(p<0.05)$ by pairwise test are linked with an ' $x$ '

\begin{tabular}{|c|c|c|c|c|c|}
\hline Parameter & Factor & df & Pseudo- $F$ & $\mathrm{p}$ & Pairwise test \\
\hline \multirow{3}{*}{ Body length } & Species & 2,93 & 255.28 & 0.0001 & \multirow{3}{*}{$\begin{array}{l}\mathrm{GM} \times \mathrm{ES} / \mathrm{CM} \times \mathrm{ES} \\
\mathrm{GM} / \mathrm{CM}\end{array}$} \\
\hline & Sex & 1,93 & 21.172 & 0.0001 & \\
\hline & Species $\times$ Sex & 2,93 & 2.531 & 0.0831 & \\
\hline \multirow[t]{3}{*}{ Body mass } & Species & 2,93 & 1215.2 & 0.0001 & \multirow{3}{*}{$\begin{array}{l}\mathrm{GM} \times \mathrm{ES} \times \mathrm{CM} \\
\mathrm{GM} / \mathrm{CM}\end{array}$} \\
\hline & Sex & 1,93 & 86.616 & 0.0001 & \\
\hline & Species $\times$ Sex & 2,93 & 24.443 & 0.0001 & \\
\hline \multirow[t]{3}{*}{$\delta^{15} \mathrm{~N}$} & Species & 2,93 & 209.5 & 0.0001 & \multirow[t]{3}{*}{$\mathrm{GM} \times \mathrm{ES} \times \mathrm{CM}$} \\
\hline & Sex & 1,93 & 0.001 & 0.9727 & \\
\hline & Species $\times$ Sex & 2,93 & 3.4024 & 0.0398 & \\
\hline \multirow[t]{3}{*}{$\delta^{13} \mathrm{C}$} & Species & 2,93 & 91.734 & 0.0001 & \multirow[t]{3}{*}{$\mathrm{GM} \times \mathrm{ES} \times \mathrm{CM}$} \\
\hline & Sex & 1,93 & 0.81142 & 0.3693 & \\
\hline & Species $\times$ Sex & 2,93 & 0.89135 & 0.4162 & \\
\hline
\end{tabular}

Table 3. Diet composition of Galeus melastomus, Etmopterus spinax and Chimaera monstrosa from the Gulf of Lion (NW Mediterranean), expressed as frequency of occurrence $(\% \mathrm{FO})$, number $(\% \mathrm{~N})$, mass $(\% \mathrm{~W})$ and the index of relative importance (\% IRI)

\begin{tabular}{|c|c|c|c|c|c|c|c|c|c|c|c|c|}
\hline & \multicolumn{4}{|c|}{ Galeus melastomus } & \multicolumn{4}{|c|}{ Etmopterus spinax } & \multicolumn{4}{|c|}{ Chimaera monstrosa } \\
\hline & $\% \mathrm{FO}$ & $\% \mathrm{~N}$ & $\% W$ & \%IRI & $\% \mathrm{FO}$ & $\% \mathrm{~N}$ & $\% \mathrm{~W}$ & \%IRI & $\% \mathrm{FO}$ & $\% \mathrm{~N}$ & $\% W$ & \%IRI \\
\hline Fish & 35.48 & 13.59 & 14.30 & 12.10 & 15.79 & 10.00 & 73.24 & 17.79 & 12.50 & 1.86 & 34.17 & 2.93 \\
\hline Shrimp & 25.81 & 17.48 & 78.93 & 30.43 & 52.63 & 43.33 & 20.66 & 45.60 & - & - & - & - \\
\hline Crab & 25.81 & 7.77 & 1.81 & 3.02 & 5.26 & 3.33 & 0.01 & 0.24 & 91.67 & 96.89 & 65.55 & 96.98 \\
\hline Cephalopod & 80.65 & 44.66 & 3.25 & 47.26 & 5.26 & 3.33 & 0.01 & 0.24 & - & - & - & - \\
\hline Unidentified & 32.26 & 16.50 & 1.70 & 7.18 & 57.89 & 40.00 & 6.09 & 36.13 & 8.33 & 1.24 & 0.28 & 0.08 \\
\hline
\end{tabular}




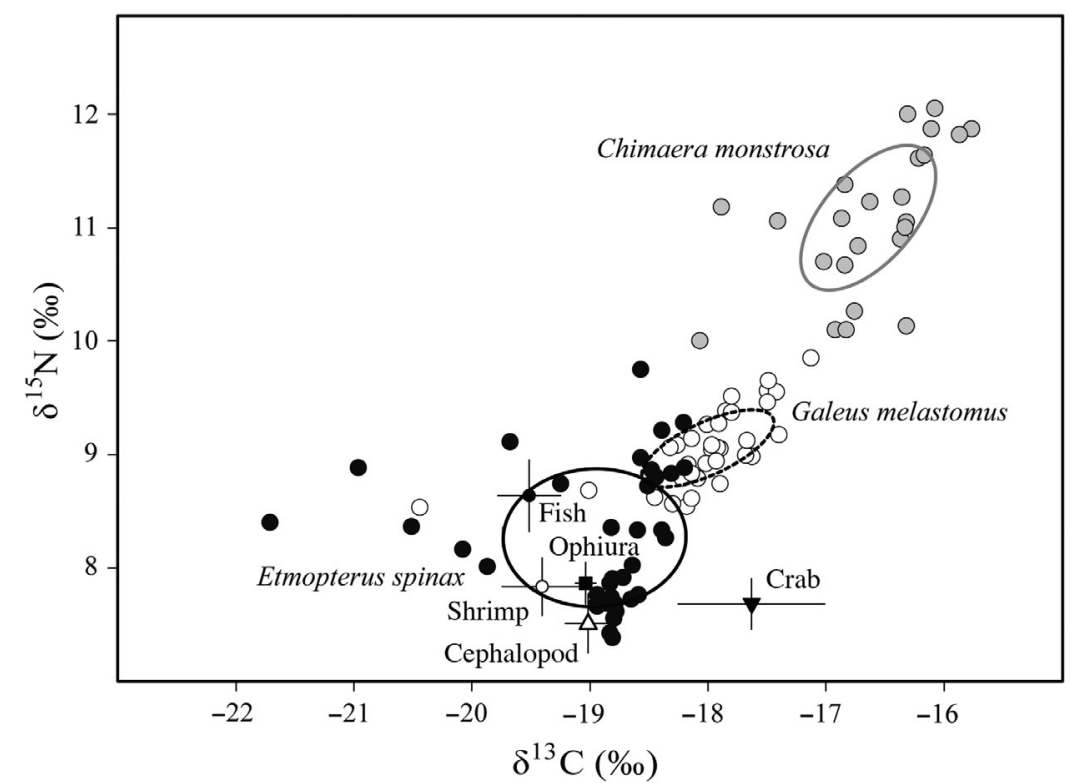

Fig. 2. $\delta^{15} \mathrm{~N}$ and $\delta^{13} \mathrm{C}$ values of potential prey groups and of Galeus melastomus (white circles), Etmopterus spinax (black circles) and Chimaera monstrosa (grey circles). Isotopic Bayesian ellipse areas for each species were also indicated

\section{Stable isotope analysis}

The $\delta^{13} \mathrm{C}$ and $\delta^{15} \mathrm{~N}$ values of males and females did not differ within any of the 3 species analysed, whereas statistically significant differences were observed for both parameters among the 3 species (Table 2, Fig. 2). The isotopic core niche space $\left(\mathrm{SEA}_{\mathrm{C}}\right)$ of $C$. monstrosa did not overlap with the other 2 species, whereas G. melastomus and $E$. spinax presented a small isotopic niche overlap $(0.47 \%)$, suggesting niche partitioning between species (Fig. 2). Niche width was larger for E. spinax $\left(\mathrm{SEA}_{\mathrm{C}}=1.53 \%{ }^{2}\right)$ compared to $C$. monstrosa $\left(\mathrm{SEA}_{\mathrm{C}}=0.98 \%{ }^{2}\right.$ ) and G. melastomus ( $\mathrm{SEA}_{\mathrm{C}}=0.46 \%{ }^{2}$ ) (Fig. 2). Although the major part of individuals of each species showed similar isotopic values between them, indicating a similar source of carbon for all them (Fig. 2), few specimens of E. spinax and 1 specimen of G. melastomus were extremely depleted in $\delta^{13} \mathrm{C}$, thus suggesting the use of a different source of carbon (Fig. 2). Regarding the correlation between $\delta^{15} \mathrm{~N}$ and body length, G. melastomus and E. spinax showed a positive and significantly relationship (p < 0.001), whereas $C$. monstrosa did not show a relationship between $\mathrm{N}$ isotopic values and body length (Fig. 3). For C isotopic values, only G. melastomus showed a positive significant relationship ( $\mathrm{p}=0.005)$.

The feasible contribution of each potential prey, as estimated by SIAR models with varying DTDF (Figs. 4 \& 5; Table S1 in Supplement 2 at www. int-res.com/articles/suppl/524p255_supp.pdf), differed among species. Overall, for the different DTDF, cephalopods were the most important assimilated prey for G. melastomus (Figs. 4A,B \& 5), shrimps dominated the diet of E. spinax (Figs. 4D-F \& 5), and crabs were the dominant prey for C. monstrosa (Figs. 4G-I \& 5).

\section{Trophic levels}

Trophic levels estimated using isotopic values ( $\mathrm{TL}_{\text {siai }}$ Fig. 3) and stomach content analysis ( $\mathrm{TL}_{\text {stomach }}$ ) were similar for G. melastomus and E. spinax (G. melastomus: $\mathrm{TL}_{\text {sia }}=3.74 \pm 0.15, \mathrm{TL}_{\text {stomach }}=4.17 ; \mathrm{E}$.

Fig. 3. Relationships between the body length (anal length, $\mathrm{cm})$, estimated trophic level and (A) $\delta^{15} \mathrm{~N}$ and (B) $\delta^{13} \mathrm{C}$ of Galeus melastomus, Etmopterus spinax and Chimaera monstrosa 


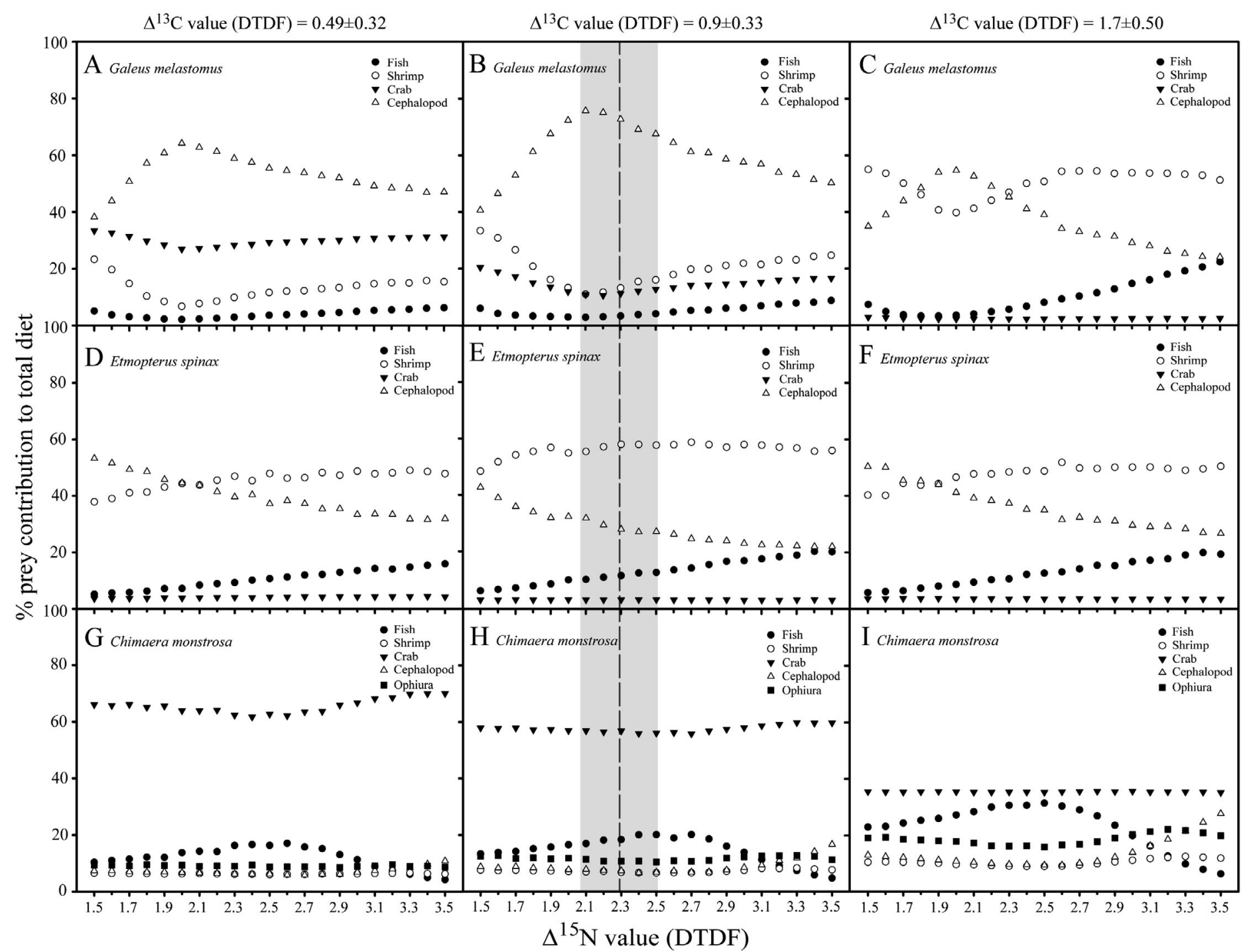

Fig. 4. Results of the SIAR model, showing mean estimated prey contributions to the diet of (A-C) Galeus melastomus, (D-F) Etmopterus spinax and (G-I) Chimaera monstrosa from the Gulf of Lions (NW Mediterranean) using incremental diet-tissue discrimination factor $\left(\Delta^{15} \mathrm{~N}\right.$ ) and 3 different $\Delta^{13} \mathrm{C}$ (means $\pm \mathrm{SD}: 0.49 \pm 0.32$ and $0.90 \pm 0.33$, Hussey et al. 2010b; 1.70 $\pm 0.50, \mathrm{Kim}$ et al. 2012). Dashed vertical line and grey area represent the mean DTDF for $\Delta^{15} \mathrm{~N}$ (mean \pm SD: $2.29 \pm 0.22$ ) defined by Hussey et al. (2010b)

spinax: $\left.\mathrm{TL}_{\text {sia }}=3.39 \pm 0.27, \mathrm{TL}_{\text {stomach }}=3.71\right)$. For $C$. monstrosa, TL was different between $\mathrm{TL}_{\text {stomach }}$ and $\mathrm{TL}_{\text {sia }}$ values, the latter being clearly higher $\left(\mathrm{TL}_{\text {sia }}=\right.$ $\left.4.62 \pm 0.28, \mathrm{TL}_{\text {stomach }}=3.54\right)$. Regarding $\mathrm{TL}_{\text {sia }}$, C. monstrosa presented the highest values, whereas the highest observed $\mathrm{TL}_{\text {stomach }}$ values were found for $E$. spinax.

\section{DISCUSSION}

By combining information obtained from stomach content and stable isotope analyses, we provide new information on the feeding habits (diet composition, trophic niche and trophic level) of 3 species of chondrichthyans coexisting in the NW Mediterranean Sea. Although some qualitative differences between methods were found, both stomach content and stable isotope analyses revealed differences in the main isotopic niche space and trophic levels occupied by each species.

\section{Feeding habits of 3 sympatric demersal chondrichthyans}

The holocephalan Chimaera monstrosa showed a diet mainly composed of crabs, as previously re- 

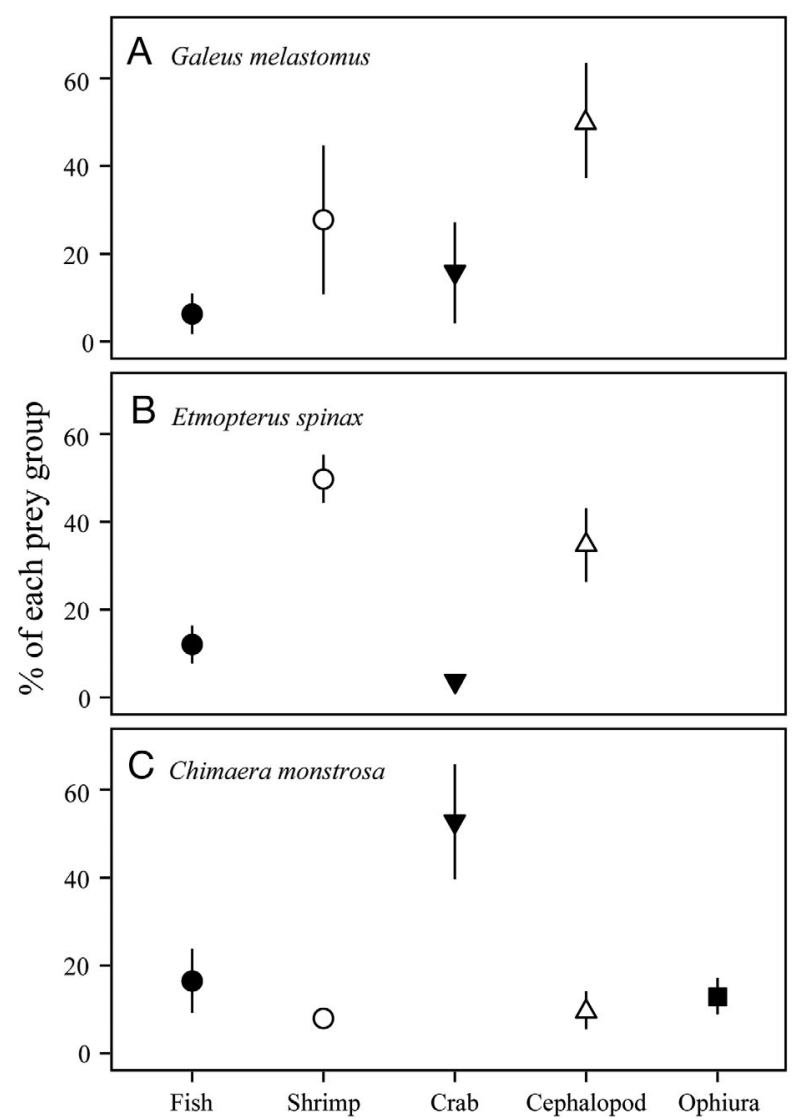

Fig. 5. Means $( \pm \mathrm{SD})$ of the results of the SIAR model using incremental diet-tissue discrimination factor $\left(\Delta^{15} \mathrm{~N}\right)$ and 3 different $\Delta^{13} \mathrm{C}$ (means \pm SD: $0.49 \pm 0.32$ and $0.90 \pm 0.33$, Hussey et al. $2010 b ; 1.70 \pm 0.50$, Kim et al. 2012) to the diet of (A) Galeus melastomus, (B) Etmopterus spinax, and (C) Chimaera monstrosa from the Gulf of Lions (NW Mediterranean)

ported (MacPherson 1980, Moura et al. 2005, Torres et al. 2012). However, despite previous studies indicated the importance of ophiurid species in its diet (MacPherson 1980, Moura et al. 2005), this benthic prey was not found in any stomachs analysed during this study, and the isotopic results suggested a low contribution of ophiurans to the diet of C. monstrosa. Ophiurans have been reported as more abundant in locations overexploited via bottom trawling (Tuck et al. 1998, Smith et al. 2000). This low presence of ophiurans in the stomach of C. monstrosa in our study could be due to the lower level of fishery exploitation in the Gulf of Lions study area in comparison to other areas of the western Mediterranean Sea (Massutí et al. 2012).

The high level of occurrence of prey items with hard structures (crabs) in the diet of C. monstrosa (MacPherson 1980, Moura et al. 2005, this study) is probably related to the jaw morphology of C. mon- strosa, which has interconnected pavement teeth, forming a dental plate that allows for the crushing of hard structures such as crab carapaces (Didier et al. 1994). This different capability may allow C. monstrosa to segregate from Galeus melastomus and Etmopterus spinax, which prey on benthopelagic species without hard structures like cephalopods, shrimps or fishes.

The preferred prey groups of G. melastomus were cephalopods and shrimps. This is in agreement with what has been reported for lower slope populations (984 to $1584 \mathrm{~m}$ depth), whereas for G. melastomus inhabiting the middle slope (371 to $667 \mathrm{~m}$ ), cephalopods were scarce in the stomach contents studied by Carrassón et al. (1992). Differences in reported diets may be due to variations in the proportion of prey in the different seasons and group sizes. MacPherson (1979) reported higher percentages of cephalopods in the diet of $G$. melastomus during the summer season as well. Moreover, larger G. melastomus may efficiently prey on fast-moving cephalopods (MacPherson 1979, Olaso et al. 2005).

G. melastomus and E. spinax slightly overlap their trophic isotopic niche, as has already been described in the Mediterranean and Atlantic waters (MacPherson 1980, Preciado et al. 2009, Valls et al. 2011). In agreement with our results, Coelho et al. (2009) reported crustaceans as the dominant prey group of $E$. spinax. The small size of the individuals of $E$. spinax studied here may explain the prevalence of shrimps in the diet and differences in diet compared to G. melastomus. Both species presented a clear size-based relationship, highlighting that differences in isotope values between both species are probably due to differences in body length and ontogenetic stages. Ontogenetic shifts in diet for elasmobranchs have been reported (Wetherbee \& Cortés 2004) and also an increase in $\delta^{15} \mathrm{~N}$ with size (Hussey et al. 2011). Previous authors have found an ontogenetic dietary shift for E. spinax, involving an increase in the consumption of cephalopods with size (MacPherson 1979). Furthermore, E. spinax move to deeper waters as they grow (Coelho 2007). This could be the reason that all the individuals in the present study were immature and significantly smaller than G. melastomus caught at the same depth. However, other reasons such as the declining of E. spinax in the Mediterranean and a possible lower catchability of adults with trawls (Cartes et al. 2013) could explain also the differences in body size of the species sampled.

Nevertheless, some specimens of E. spinax were highly depleted in ${ }^{13} \mathrm{C}$, which suggests foraging in 
other areas. The organic matter of terrestrial origin transported by river runoff to the Gulf of Lions is depleted in ${ }^{13} \mathrm{C}$ compared to the particulate organic matter of planktonic origin (Darnaude et al. 2004). Those differences are conserved in 2 parallel food webs including, respectively, deposit-feeding polychaetes and their predators and suspension feeders and molluscs and their predators (Darnaude et al. 2004). The highly negative values of some specimens of E. spinax suggest foraging in areas highly influenced by the Rhone River plume, which is consistent with the occurrence of immature specimens of shallow shelf habitats (Sion et al. 2004, Neiva et al. 2006, Fanelli et al. 2009, Valls et al. 2011). Moreover, segregation in feeding time in marine predators has also been described as a mechanism of coexistence (Lowe et al. 1996, Pusineri et al. 2008, Navarro et al. 2013a). E. spinax has been described as a predominantly diurnal species, while G. melastomus is thought to favour nocturnal activity (Wurtz \&Vacchi 1978, Olaso et al. 2005, Atkinson \& Bottaro 2006). However, unpublished data from temporally scheduled trawl haul surveys repeated at an hourly frequency over 4 consecutive days (Supplement 3 for more details) suggests that the 3 species have similar rhythmic patterns with 2 major activity peaks toward sunset and sunrise (see Fig. S3 in Supplement 3 at www.intres.com/articles/suppl/m524p255_supp.pdf). Thus, the overall evidence indicates that the trophic niche segregation observed between G. melastomus and $E$. spinax probably are mainly caused by differences in body length and ontogenetic shifts in dietary habits.

\section{Trophic role and position within the food web}

As expected by the interspecific differences in dietary habits, each species showed different isotopic niche space and trophic level. E. spinax showed the lowest $\mathrm{TL}_{\text {sia }}$ probably due to the fact that all individuals were immature, although the $\mathrm{TL}_{\text {stomach }}$ was slightly higher. This is probably due to the fact that the stomach content analysis overestimates the trophic level because similar trophic levels are given to different types of prey without taking into account that there are ontogenetic differences in their trophic levels. Therefore, there was a significant positive relationship between body length and $\delta^{15} \mathrm{~N}$, reflecting the influence of body size to TL. This factor may enable small-sized E. spinax to prey on smaller-sized prey items and in consequence to have a lower TL than the other 2 species. Differences between $\mathrm{TL}_{\text {sia }}$ and $\mathrm{TL}_{\text {stomach }}$ would be expected considering that the estimated trophic levels from isotope analysis are vulnerable to the basic assumption of which $\Delta^{15} \mathrm{~N}$ value and basal sources are used (Olin et al. 2013). Discrepancy between methodologies $\left(\mathrm{TL}_{\text {sia }}\right.$ and $\mathrm{TL}_{\text {stomach }}$ ) revealed the need for caution when values of trophic levels are compared. E. spinax and $G$. melastomus did not show important differences between both methodologies.

TL results for $G$. melastomus also showed a higher trophic position when analysed by means of stomach content analysis. In this analysis, the main prey was cephalopods, but cephalopods are a diverse group, and it is known that their trophic position can substantially vary between species (Coll et al. 2013a, Navarro et al. 2013b). Therefore, we could have been overestimating the trophic position of the predator when using a mean value of trophic level derived from that group (Hussey et al. 2011). In the case of $C$. monstrosa, the trophic level estimated by stable isotopes was higher than the trophic level estimated by stomach content results. Although both methodologies revealed that the diet of C. monstrosa is composed mainly of crabs, the isotopic mixing model output indicated that fish is also important in its diet, increasing the trophic level estimated with isotopic data.

When compared with other studies available in the literature, our TL estimates from stomach content analysis are very similar to available estimates (e.g. E. spinax $\mathrm{TL}=3.8 \pm 0.5$, G. melastomus $\mathrm{TL}=4.2 \pm 0.6$, and C. monstrosa TL $=3.5 \pm 0.6$; Froese \& Pauly 2013), highlighting the important role of the studied species as predators in the marine food web. Specifically, C. monstrosa occupies a similar trophic position to other predators in the area like European hake Merluccius merluccius or Atlantic bonito Sarda sarda (Coll et al. 2006, Navarro et al. 2011, Bănaru et al. 2013). G. melastomus and E. spinax showed trophic ositions similar to some other benthic predatory fishes, seabirds and other deep-sea elasmobranchs of the western Mediterranean (Navarro et al. 2011, 2013c, Bănaru et al. 2013, Coll et al. 2013b).

There are several studies that have identified many factors that contribute to variation in isotopic signatures as well as limitations in the stomach content analyses, and it is important that their limitations are understood (Phillips et al. 2014); hence, it is possible that some of these limitations may have biased our results. For stomach content analysis, that factors are the number of stomachs analysed, empty stomachs, rapid digestion of soft prey items and the period of time that stomach content integrates (Hobson et al. 1994, Pinnegar \& Polunin 1999). In the case of stable 
isotope analysis, temporal and spatial variation of stable isotope is one of the main factors to take into account (Boecklen et al. 2011). Application of mixing models for dietary reconstruction is vulnerable to the variation in DTDF (Caut et al. 2009, Olin et al. 2013, Hussey et al. 2014) and to an effective characterization of the proper food sources (Fry 2013, Phillips et al. 2014). In addition to all these limitations, as we have shown in this study, the combination of both methodologies and a good comprehension of the selected study system allow improvement of the understanding of trophic interactions.

In conclusion, based on stable isotopic and stomach results, we found that the 3 species studied exploited different trophic resources, segregating in their trophic niche, likely due to different feeding capabilities, different bathymetric distribution depending on body size and different ontogenetic stages among species, but not due to different biorhythms. These results provide new insights into the mechanisms supporting the coexistence of deep-water demersal predators and their ecological role. From a technical perspective, our study revealed the advantages of integrating results from stomach content and stable isotope analyses to obtain information on the feeding habits of demersal predators integrating different time periods, from days to months. This strategy allows a more efficient monitoring of marine food web changes and can be especially important for the study of marine predators and deep-sea organisms, which are not always accessible for sampling in large numbers.

Acknowledgements. We thank Isabel Palomera for her encouragement and support and fishermen from Port de la Selva and Llançà for helping with sample collection. Ricardo Álvarez helped in the stable isotope analysis. M.A.-P. was supported by a predoctoral fellowship of the FPI program (Spanish Ministry of Economy and Competitiveness). J.N. was supported by a research contract of the Marie Curie GIC project BioWeb. M.C. and J.A. are supported by a postdoctoral contract of the Ramon y Cajal Program (Spanish Ministry of Economy and Competiveness), and M.C. was also supported by BioWeb project. This study is a contribution to the project ECOTRANS (CTM2011-26333, Ministerio de Economía y Competitividad, Spain). The authors declare that all experimental procedures were conducted in strict accordance with good animal practice as defined by the current Spanish, Catalonian and European legislation.

\section{LITERATURE CITED}

Abdul Malak D, Livingstone S, Pollard D, Polidoro BA and others (2011) Overview of the conservation status of the marine fishes of the Mediterranean Sea. IUCN, Gland

Anderson M, Gorley R, Clarke K (2008) PERMANOVA+ for
PRIMER: guide to software and statistical methods. PRIMER-E, Plymouth

Atkinson CJL, Bottaro M (2006) Ampullary pore distribution of Galeus melastomus and Etmopterus spinax: possible relations with predatory lifestyle and habitat. J Mar Biol Assoc UK 86:447-448

Bănaru D, Mellon-Duval C, Roos D, Bigot JL and others (2013) Trophic structure in the Gulf of Lions marine ecosystem (north-western Mediterranean Sea) and fishing impacts. J Mar Syst 111-112:45-68

Bautista-Vega AA, Letourneur Y, Harmelin-Vivien M, Salen-Picard C (2008) Difference in diet and size-related trophic level in two sympatric fish species, the red mullets Mullus barbatus and Mullus surmuletus, in the Gulf of Lions (north-west Mediterranean Sea). J Fish Biol 73: 2402-2420

Boecklen WJ, Yarnes CT, Cook BA, James AC (2011) On the use of stable isotopes in trophic ecology. Annu Rev Ecol Evol Syst 42:411-440

> Calis E, Jackson E, Nolan C, Jeal F (2005) Preliminary age and growth estimates of the rabbitfish, Chimaera monstrosa, with implications for future resource management. J Northwest Atl Fish Sci 35:15-26

Capape C, Bradaï M, Seck A, Diata Y (2001) Aspects of the reproductive biology of the Velvet Belly, Etmopterus spinax (Elasmobranchii: Squalidae). Bull Inst Natl Sci Tech Oceanogr Peche Salammbò 28:55-64

> Carlier A, Riera P, Amouroux JM, Bodiou JY, Grémare A (2007) Benthic trophic network in the Bay of Banyuls-surMer (northwest Mediterranean, France): an assessment based on stable carbon and nitrogen isotopes analysis. Estuar Coast Shelf Sci 72:1-15

> Carrassón M, Stefanescu C, Cartes JE (1992) Diets and bathymetric distributions of two bathyal sharks of the Catalan deep sea (western Mediterranean). Mar Ecol Prog Ser 82:21-30

> Cartes JE, Fanelli E, Lloris D, Matallanas J (2013) Effect of environmental variations on sharks and other top predators in the deep Mediterranean Sea over the last 60 years. Clim Res 55:239-251

- Caut S, Angulo E, Courchamp F (2009) Variation in discrimination factors $\left(\Delta^{15} \mathrm{~N}\right.$ and $\left.\Delta^{13} \mathrm{C}\right)$ : the effect of diet isotopic values and applications for diet reconstruction. J Appl Ecol 46:443-453

> Caut S, Jowers MJ, Michel L, Lepoint G, Fisk AT (2013) Diet- and tissue-specific incorporation of isotopes in the shark Scyliorhinus stellaris, a North Sea mesopredator. Mar Ecol Prog Ser 492:185-198

Cherel Y, Le Corre M, Jaquemet S, Ménard F, Richard P, Weimerskirch $H$ (2008) Resource partitioning within a tropical seabird community: new information from stable isotopes. Mar Ecol Prog Ser 366:281-291

- Cherel Y, Fontaine C, Jackson GD, Jackson CH, Richard P (2009) Tissue, ontogenic and sex-related differences in $\delta^{13} \mathrm{C}$ and $\delta^{15} \mathrm{~N}$ values of the oceanic squid Todarodes filippovae (Cephalopoda: Ommastrephidae). Mar Biol 156:699-708

> Chiaradia A, Forero MG, Hobson KA, Swearer SE, Hume F, Renwick L, Dann P (2012) Diet segregation between two colonies of little penguins Eudyptula minor in southeast Australia. Austral Ecol 37:610-619

Coelho R (2007) Biology, population dynamics, management and conservation of deep water lantern shark, Etmopterus spinax and Etmopterus pusillus (Chondrichthyes: Etmopteridae) in southern Portugal (northeast Atlantic). 
PhD thesis, Universidade do Algarve

Coelho R, Blasdale T, Mancusi C, Serena F and others (2009) Etmopterus spinax. In: IUCN 2012. IUCN Red List of Threatened Species. www.iucnredlist.org (accessed 11 Aug 2012)

Coll M, Palomera I, Tudela S, Sarda F (2006) Trophic flows, ecosystem structure and fishing impacts in the South Catalan Sea, Northwestern Mediterranean. J Mar Syst 59:63-96

> Coll M, Piroddi C, Albouy C, Ben Rais Lasram F and others (2012) The Mediterranean Sea under siege: spatial overlap between marine biodiversity, cumulative threats and marine reserves. Glob Ecol Biogeogr 21:465-480

Coll M, Navarro J, Olson RJ, Christensen V (2013a) Assessing the trophic position and ecological role of squids in marine ecosystems by means of food-web models. DeepSea Res II 95:21-36

Coll M, Navarro J, Palomera I (2013b) Ecological role, fishing impact, and management options for the recovery of a Mediterranean endemic skate by means of food web models. Biol Conserv 157:108-120

Cortés E (1997) A critical review of methods of studying fish feeding based on analysis of stomach contents: application to elasmobranch fishes. Can J Fish Aquat Sci 54: 726-738

Cortés E (1999) Standardized diet compositions and trophic levels of sharks. ICES J Mar Sci 56:707-717

> Costalago D, Navarro J, Álvarez-Calleja I, Palomera I (2012) Ontogenetic and seasonal changes in the feeding habits and trophic levels of two small pelagic fish species. Mar Ecol Prog Ser 460:169-181

> Darnaude AM, Salen-Picard C, Polunin NVC, HarmelinVivien ML (2004) Trophodynamic linkage between river runoff and coastal fishery yield elucidated by stable isotope data in the Gulf of Lions (NW Mediterranean). Oecologia 138:325-332

> Didier DA, Stahl BJ, Zangerl R (1994) Development and growth of compound tooth plates in Callorhinchus milii (chondrichthyes, holocephali). J Morphol 222:73-89

Estrada M (1996) Primary production in the northwestern Mediterranean. Sci Mar 60:55-64

Fanelli E, Rey J, Torres P, Gil de Sola L (2009) Feeding habits of blackmouth catshark Galeus melastomus Rafinesque, 1810 and velvet belly lantern shark Etmopterus spinax (Linnaeus, 1758) in the western Mediterranean. J Appl Ichthyology 25:83-93

Froese R, Pauly D (2013) FishBase. World Wide Web electronic publication. www.fishbase.org (accessed 17 Dec 2013)

- Fry B (2013) Alternative approaches for solving underdetermined isotope mixing problems. Mar Ecol Prog Ser 472: $1-13$

Gause GF (1934) The struggle for existence. Williams and Wilkins, Baltimore, MD

- Gennari E, Scacco U (2007) First age and growth estimates in the deep water shark, Etmopterus spinax (Linnaeus, 1758), by deep coned vertebral analysis. Mar Biol 152: 1207-1214

Grant PR (1972) Convergent and divergent character displacement. Biol J Linn Soc 4:39-68

> Hobson KA, Piatt JF, Pitochelli J (1994) Using stable isotopes to determine seabird trophic relationship. J Anim Ecol 63:786-798

Hussey NE, MacNeil MA, Fisk AT (2010a) The requirement for accurate diet-tissue discrimination factors for interpreting stable isotopes in sharks. Hydrobiologia 654:1-5

Hussey NE, Brush J, McCarthy ID, Fisk AT (2010b) $\delta^{15} \mathrm{~N}$ and $\delta^{13} \mathrm{C}$ diet-tissue discrimination factors for large sharks under semi-controlled conditions. Comp Biochem Physiol A Mol Integr Physiol 155:445-453

Hussey NE, Dudley SFJ, McCarthy ID, Cliff G, Fisk AT (2011) Stable isotope profiles of large marine predators: viable indicators of trophic position, diet, and movement in sharks? Can J Fish Aquat Sci 68:2029-2045

Hussey NE, MacNeil MA, Olin JA, McMeans BC, Kinney MJ, Chapman DD, Fisk AT (2012) Stable isotopes and elasmobranchs: tissue types, methods, applications and assumptions. J Fish Biol 80:1449-1484

> Hussey NE, MacNeil MA, Bailey CM, Olin JA and others (2014) Rescaling the trophic structure of marine food webs. Ecol Lett 17:239-250

> Hyslop EJ (1980) Stomach content analysis - a review of methods and their application. J Fish Biol 17:411-429

> Jackson AL, Inger R, Parnell AC, Bearhop S (2011) Comparing isotopic niche widths among and within communities: SIBER - Stable Isotope Bayesian Ellipses in R. $\mathrm{J}$ Anim Ecol 80:595-602

- Kelly J (2000) Stable isotopes of carbon and nitrogen in the study of avian and mammalian trophic ecology. Can J Zool 78:1-27

> Kim SL, Casper DR, Galván-Magaña F, Ochoa-Díaz R, Hernández-Aguilar SB, Koch PL (2012) Carbon and nitrogen discrimination factors for elasmobranch soft tissues based on a long-term controlled feeding study. Environ Biol Fishes 95:37-52

Kiszka J, Simon-Bouhet B, Martinez L, Pusineri C, Richard P, Ridoux V (2011) Ecological niche segregation within a community of sympatric dolphins around a tropical island. Mar Ecol Prog Ser 433:273-288

- Layman CA, Araujo MS, Boucek R, Hammerschlag-Peyer $\mathrm{CM}$ and others (2012) Applying stable isotopes to examine food-web structure: an overview of analytical tools. Biol Rev Camb Philos Soc 87:545-562

> Logan JM, Jardine TD, Miller TJ, Bunn SE, Cunjak RA, Lutcavage ME (2008) Lipid corrections in carbon and nitrogen stable isotope analyses: comparison of chemical extraction and modelling methods. J Anim Ecol 77: 838-846

Lowe CG, Wetherbee BM, Crow GL, Tester AL (1996) Ontogenetic dietary shifts and feeding behavior of the tiger shark, Galeocerdo cuvier, in Hawaiian waters. Environ Biol Fishes 47:203-211

MacNeil MA, Skomal GB, Fisk AT (2005) Stable isotopes from multiple tissues reveal diet switching in sharks. Mar Ecol Prog Ser 302:199-206

MacPherson E (1979) Estudio sobre las relaciones tróficas en peces bentónicos de la costa catalana. PhD thesis, Universitat de Barcelona

- MacPherson E (1980) Food and feeding of Chimaera monstrosa, Linnaeus 1758, in the western Mediterranean. J Cons 39:26-29

> Martínez del Rio C, Wolf N, Carleton SA, Gannes LZ (2009) Isotopic ecology ten years after a call for more laboratory experiments. Biol Rev Camb Philos Soc 84:91-111

Massutí E, Ordinas F, González N, Pérez A and others (2012) Informe del seguimiento científico de la acción piloto RAI/AP-26/2007: pesca experimental con arte de arrastre de fondo en el Golfo de León (Mediterráneo Noroccidental). Instituto Español de Oceanografia, Mallorca 
Mèndez-Fernandez $\mathrm{P}$, Bustamante $\mathrm{P}$, Bode A, Chouvelon T and others (2012) Foraging ecology of five toothed whale species in the Northwest Iberian Peninsula, inferred using carbon and nitrogen isotope ratios. J Exp Mar Biol Ecol 413:150-158

Moreno R, Jover L, Munilla I, Velando A, Sanpera C (2010) A three-isotope approach to disentangling the diet of a generalist consumer: the yellow-legged gull in northwest Spain. Mar Biol 157:545-553

> Moura T, Figueiredo I, Machado PB, Gordo LS (2004) Growth pattern and reproductive strategy of the holocephalan Chimaera monstrosa along the Portuguese continental slope. J Mar Biol Assoc UK 84:801-804

Moura T, Figueiredo I, Bordalo-Machado P, Gordo LS (2005) Feeding habits of Chimaera monstrosa L. (Chimaeridae) in relation to its ontogenetic development on the southern Portuguese continental slope. Mar Biol Res 1: 118-126

Navarro J, Coll M, Louzao M, Palomera I, Delgado A, Forero MG (2011) Comparison of ecosystem modelling and isotopic approach as ecological tools to investigate food webs in the NW Mediterranean Sea. J Exp Mar Biol Ecol 401:97-104

- Navarro J, Votier SC, Aguzzi J, Chiesa JJ, Forero MG, Phillips RA (2013a) Ecological segregation in space, time and trophic niche of sympatric planktivorous petrels. PLoS ONE 8:e62897

> Navarro J, Coll M, Somes CJ, Olson RJ (2013b) Trophic niche of squids: insights from isotopic data in marine systems worldwide. Deep-Sea Res II 95:93-102

> Navarro J, Coll M, Preminger M, Palomera I (2013c) Feeding ecology and trophic position of a Mediterranean endemic ray: consistency between sexes, maturity stages and seasons. Environ Biol Fishes 96:1315-1328

> Navarro J, López L, Coll M, Barría C, Sáez-Liante R (2014) Short- and long-term importance of small sharks in the diet of the rare deep-sea shark Dalatias licha. Mar Biol 161:1697-1707

Neiva J, Coelho R, Erzini K (2006) Feeding habits of the velvet belly lanternshark Etmopterus spinax (Chondrichthyes: Etmopteridae) off the Algarve, southern Portugal. J Mar Biol Assoc UK 86:835-841

> Olaso I, Velasco F, Sánchez F, Serrano A, Rodríguez-Cabello C, Cendrero O (2005) Trophic relations of lesser-spotted catshark (Scyliorhinus canicula) and blackmouth catshark (Galeus melastomus) in the Cantabrian Sea. J Northwest Atl Fish Sci 37:481-494

> Olin JA, Hussey NE, Fritts M, Heupel MR, Simpfendorfer CA, Poulakis GR, Fisk AT (2011) Maternal meddling in neonatal sharks: implications for interpreting stable isotopes in young animals. Rapid Commun Mass Spectrom 25:1008-1016

> Olin JA, Hussey NE, Grgicak-Mannion A, Fritts MW, Wintner SP, Fisk AT (2013) Variable $\delta^{15} \mathrm{~N}$ diet-tissue discrimination factors among sharks: implications for trophic position, diet and food web models. PLoS ONE 8:e77567

Papastamatiou YP, Wetherbee BM, Lowe CG, Crow GL (2006) Distribution and diet of four species of carcharhinid shark in the Hawaiian Islands: evidence for resource partitioning and competitive exclusion. Mar Ecol Prog Ser 320:239-251

Papiol V, Cartes JE, Fanelli E, Rumolo P (2013) Food web structure and seasonality of slope megafauna in the NW Mediterranean elucidated by stable isotopes: relationship with available food sources. J Sea Res 77:53-69
Parnell AC, Inger R, Bearhop S, Jackson AL (2010) Source partitioning using stable isotopes: coping with too much variation. PLoS ONE 5:e9672

Phillips DL, Inger R, Bearhop S, Jackson AL and others (2014) Best practices for use of stable isotope mixing models in food web studies. Can J Zool 92:823-835

Pianka ER (2000) Evolutionary ecology. Addison Wesley, San Francisco, CA

Pinkas L, Oliphant MS, Iverson ILK (1971) Food habits of albacore, bluefin tuna, and bonito in California waters. Calif Fish Game 152:1-105

> Pinnegar JK, Polunin NVC (1999) Differential fractionation of $\delta^{13} \mathrm{C}$ and $\delta^{15} \mathrm{~N}$ among fish tissues: implications for the study of trophic interactions. Funct Ecol 13:225-231

> Platell ME, Potter IC (2001) Partitioning of food resources amongst 18 abundant benthic carnivorous fish species in marine waters on the lower west coast of Australia. J Exp Mar Biol Ecol 261:31-54

Preciado I, Cartes JE, Serrano A, Velasco F, Olaso I, Sánchez F, Frutos I (2009) Resource utilization by deep-sea sharks at the Le Danois Bank, Cantabrian Sea, north-east Atlantic Ocean. J Fish Biol 75:1331-1355

> Pusineri C, Chancollon O, Ringelstein J, Ridoux V (2008) Feeding niche segregation among the Northeast Atlantic community of oceanic top predators. Mar Ecol Prog Ser 361:21-34

R Development Core Team (2009) R: a language and environment for statistical computing. R Foundation for Statistical Computing, Vienna. www.r-project.org

> Ramos R, Ramírez F, Sanpera C, Jover L, Ruiz X (2009) Feeding ecology of yellow-legged gulls Larus michahellis in the western Mediterranean: a comparative assessment using conventional and isotopic methods. Mar Ecol Prog Ser 377:289-297

Rey J, de Sola LG, Massutí E (2004) Distribution and biology of the Blackmouth Catshark Galeus melastomus in the Alboran Sea (Southwestern Mediterranean). J Northwest Atl Fish Sci 37:215-223

Shiffman DS, Gallagher AJ, Boyle MD, HammerschlagPeyer CM, Gammerschlag N (2012) Stable isotope analysis as a tool for elasmobranch conservation research: a primer for non-specialists. Mar Freshw Res 63:635-643

Sion L, Bozzano A, D'Onghia G, Capezzuto F, Panza M (2004) Chondrichthyes species in deep waters of the Mediterranean Sea. Sci Mar 68:153-162

> Smith C, Papadopoulo KN, Diliberto S (2000) Impact of otter trawling on an eastern Mediterranean commercial trawl fishing ground. ICES J Mar Sci 57:1340-1351

Stehmann M (2002) Proposal of a maturity. Arch Fish Mar Res 50:23-48

Stergiou K, Karpouzi V (2002) Feeding habits and trophic levels of Mediterranean fish. Rev Fish Biol Fish 11: $217-254$

Syväranta J, Lensu A, Marjomäki TJ, Oksanen S, Jones RI (2013) An empirical evaluation of the utility of convex hull and standard ellipse areas for assessing population niche widths from stable isotope data. PLoS ONE 8: e56094

Torres MA, Gil J, Sobrino I (2012) Feeding habits of rabbit fish Chimaera monstrosa (Linnaeus, 1758) in deep waters of the Gulf of Cadiz (SW Spain). Ecosystem Based Management and monitoring in the Deep Med. \& N. Atlantic Conference, August 28-31, 2012, Galway

Tuck ID, Hall SJ, Robertson MR, Armstrong E, Basford DJ (1998) Effects of physical trawling disturbance in a previ- 
ously unfished sheltered Scottish sea loch. Mar Ecol Prog Ser 162:227-242

Turley CM, Bianchi M, Christaki U, Conan P and others (2000) Relationship between primary producers and bacteria in an oligotrophic sea - the Mediterranean and biogeochemical implications. Mar Ecol Prog Ser 193:11-18

Valls M, Quetglas A, Ordines F, Moranta J (2011) Feeding ecology of demersal elasmobranchs from the shelf and slope off the Balearic Sea (western Mediterranean). Sci Mar 75:633-639

Editorial responsibility: Ivan Nagelkerken, Adelaide, SA, Australia
Vander Zanden MJ, Rasmussen J (2001) Variation in $\delta^{15} \mathrm{~N}$ and $\delta^{13} \mathrm{C}$ trophic fractionation: implications for aquatic food web studies. Limnol Oceanogr 46:2061-2066

Wetherbee BM, Cortés E (2004) Food consumption and feeding habits. In: Carrier JC, Musick JA, Heithaus MR (eds) Biology of sharks and their relatives. CRC Press, Boca Raton, FL, p 225-246

Wurtz M, Vacchi M (1978) Ricerca di cicli nictemerali nell'alimentazione dei selaci batiali. Quad Lab Tecnol Pesca 3:155-164

Submitted: April 29, 2014; Accepted: December 25, 2014 Proofs received from author(s): March 7, 2015 